\title{
Analiza porównawcza wybranych cech eksploatacyjnych lin określonych różnymi metodami
}

\author{
Comparative analysis \\ of some rope operational features \\ obtained by different methods
}

\section{Streszczenie}

W pracy dokonano analizy porównawczej cech użytkowych lin nośnych wyciągu górniczego, określonych za pomocą badań magnetycznych (nieniszczących) i wytrzymałościowych (niszczących). Porównano siły zrywające: linę w całości - jej podstawową cechę eksploatacyjną, a także druty, tworzące splotki. Stwierdzono, że wartości uzyskane w analizowanych badaniach są zróżnicowane. Dokonano także analizy przyczyn, które taki obraz kształtowały. Na podstawie przeprowadzonych badań doświadczalnych stwierdzono, że istnieją przesłanki opracowania sposobu wyznaczania poprawek minimalizujących różnice między wartościami uzyskanymi w badaniach magnetycznych i wytrzymałościowych.

Słowa kluczowe: linowy wyciąg górniczy, lina, cecha użytkowa liny, siła zrywająca

\section{Abstract}

In this paper comparative analysis of operational features of shaft hoist rope is conducted. These features were determined by means of investigations: magnetic (non-destructive) and strength (destructive). Tensile forces: whole rope and rope strand wires are compared. It seems that values obtained by analyzed investigations are differential and depend on kind of investigations. Analysis of reasons which such image creates is realized too. On the base of conducted experimental investigations, it was found that exist premises of method determination of corrections estimation which minimize differences between features values obtained by means of magnetic and destructive strength research.

Keywords: rope hoisting shaft, rope, rope operational feature, tensile force

\section{Wstęp}

Wszelkiego rodzaju liny stanowią rodzaj artefaktu o strukturze równoległej. Charakterystyczną cechą takiej struktury jest to, że uszkodzenie jednego jej członu strukturalnego (w przypadku liny stalowej jest to drut lub we większej skali - splotka), nie powoduje całkowitej utraty zdatności całego wytworu - następuje jedynie częściowe pogorszenie jego cech użytkowych.

Badania lin określone są szczegółowo w przepisach różnej rangi, np.: [1 $\div 4$, zarówno jakościowo (zakres badań) jak i ilościowo (ich częstotliwość, dopuszczalny zakres parametrów). Są one zróżnicowane ze względu na rodzaj liny i spełniane $w$ mechanizmie funkcje, jednak w odniesieniu do wszystkich lin i zastosowań można wyróżnić dwie kategorie badań: odbiorcze i eksploatacyjne.
Pierwsze z nich - badania odbiorcze lin, przeprowadzane są u producenta i mają na celu sprawdzenie czy lina spełnia wymagania obowiązujących norm i przepisów. Na podstawie tych badań producent wystawia atest potwierdzający zgodność.

Badaniom eksploatacyjnym liny poddawane są podczas użytkowania. Mają one na celu określenie aktualnego ich stanu, głównie siły, jaką może ona przenieść.

Celem opisanych w niniejszym opracowaniu badań jest ustalenie czy między rezultatami uzyskanymi w wyniku realizacji różnych rodzajów badań istnieje zgodność, a raczej na ile różnią się one. Na podstawie

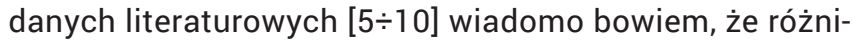
ce takie istnieją.

Prof. dr hab. inż. Michał Styp-Rekowski - Towarzystwo N-T Obrabiarek i Narzędzi SIMP; dr inż. Eugeniusz Mańka - Centrum Badań i Dozoru Górnictwa Podziemnego; dr hab. inż. Maciej Matuszewski - Uniwersytet Technologiczno-Przyrodniczy w Bydgoszczy, Wydział Inżynierii Mechanicznej.

Autor korespondencyjny/Corresponding author. matus@utp.edu.pl 


\section{Obiekt badań}

Analizę przeprowadzono na podstawie kompleksowych badań liny nośnej o następujących charakterystycznych cechach wytrzymałościowych i użytkowych [10]:

- oznaczenie liny: 34,0-6(6+12+13)+A0 - S/s - I - g 1570 PN-66/G-46602,

- struktura konstrukcyjna liny: $6(6 \times 1,38+3 \times 0,90+12 \times 1.54+1$ $3 \times 2,32)$,

- nominalny przekrój nośny $F_{n}$ (suma przekrojów wszystkich drutów o nominalnej średnicy): $517,5 \mathrm{~mm}^{2}$,

- siła zrywająca linę w całości: $755800 \mathrm{~N}$,

- suma sił zrywających wszystkie druty liny (wg świadectwa wytwórcy): $846020 \mathrm{~N}$.

Lina eksploatowana była w cztero-linowym wyciągu w szybie wdechowym o głębokości 820 m, o średnim natężeniu ruchu ok. 150 wyciągów na dobę i została zdjęta po 36 miesiącach eksploatacji na skutek korozji stwierdzonej w badaniach organoleptycznych.

Badany odcinek liny miał długość $\mathrm{L}_{0}=60 \mathrm{~m}$, a pobrano go (początek próbki) ok. 80 metrów nad naczyniem $A$ - rysunek 1.

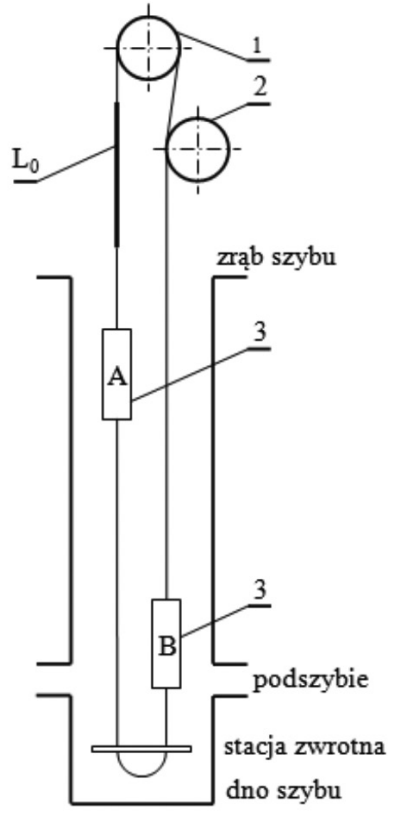

Rys. 1. Elementy strukturalne wyciągu górniczego, którego liny stanowiły obiekt badań: 1 - bęben pędny, 2 - koło dociskowe, 3 - naczynia towarowe; $L_{o}-$ miejsce pobrania próbek do badań)

Fig. 1. Structural elements of shaft hoist with ropes used as tested object: 1 - hoist wheel, 2 - steering wheel, 3 - hoisting vessels; $L_{0}$ - place of rope segment collecting

Analiza kinematyczna pracy wyciągu wskazuje, że pobrany odcinek podczas eksploatacji, w każdym cyklu pracy był jednostronnie przeginany na bębnie pędnym, był również narażony na działanie czynnika środowiskowego w szybie.

\section{Badania lin}

Opisane poniżej badania eksperymentalne przeprowadzone były zgodnie z obowiązującymi w tym zakresie normami i przepisami branżowymi [2,4]. Można podzielić je na trzy grupy:

- magnetyczne,

- organoleptyczne (wizualne),

- wytrzymałościowe.

Dwa pierwsze rodzaje to badania nieniszczące, trzecie - mają charakter niszczący. Badania organoleptyczne sprowadzają się w zasadzie do badań wizualnych. Ich wyniki mają charakter jakościowy. $\mathrm{Na}$ ich podstawie nie można określić stopnia zużycia liny, a jedynie oszacować. Z tego powodu w dalszych rozważaniach zostaną one pominięte.
Metodycznie wymienione badania różnią się znacznie, lecz uzyskane w nich wyniki wzajemnie uzupełniają się. Ze względu na różny ich charakter (nieniszczące lub niszczące) można je przeprowadzać na obiektach będących w użytkowaniu lub na ich zdemontowanych elementach. Poniżej, krótko scharakteryzowano badania magnetyczne i wytrzymałościowe.

\section{Badania magnetyczne}

Są to nieniszczące badania liny w całości, pozwalające wskazać miejsce i stopień największego jej osłabienia. Badania te bazują na czasowo-amplitudowej analizie sygnału i należą do grupy badań ilościowych - na ich podstawie można bowiem określić stopień osłabienia liny. Podczas względnego ruchu liny i źródła pola magnetycznego rejestrowany jest sygnał elektryczny generowany przez zmiany pola magnetycznego wywołanego uszkodzeniem liny. Na podstawie uzyskanych wartości wielkości przyjętych jako sygnały diagnostyczne oblicza się stopień osłabienia liny $[2,5]$. Rezultaty takich badań zapisuje się w formie defektogramu.

$\mathrm{Na}$ podstawie wyników badań magnetycznych dokonuje się oceny stanu technicznego całej liny i wyznacza odcinki najbardziej osłabione. W oparciu o analizę wyników podejmuje się następnie decyzję odnośnie dalszego jej użytkowania lub wymiany. W przypadku decyzji o wycofaniu liny z użytkowania istnieje możliwość zweryfikowania tej decyzji za pomocą badań wytrzymałościowych. W przeciwnym przypadku, prawidłowość decyzji dopuszczającej linę do dalszego użytkowania jest trudno potwierdzić - nie ma bowiem możliwości realizacji badań weryfikujących.

Interpretacja wyników badań magnetycznych, podobnie jak badań organoleptycznych, jest zależna od umiejętności i doświadczenia przeprowadzającego badania, dlatego też czynione są wysiłki, aby zminimalizować wpływ tego subiektywnego czynnika, co pozwoliłoby na zwiększenie trafności dokonywanych ocen.

\section{Badania wytrzymałościowe}

Badania z tej grupy mają charakter niszczący a wyniki pozwalają na ilościowe opisanie stanu liny, gdyż ich wyniki stanowią zbiór zmierzonych wartości wielkości fizycznych. Badania te wymagają dekompozycji odcinka liny, gdyż badaniom oprócz całego przekroju liny podlegają także jej komponenty - pojedyncze druty.

W tej grupie badań wyróżnić należy dwa przypadki. Pierwszy z nich dotyczy badań na próbce pobranej z liny pracującej (tylko dla wyciągów z napędem bębnowym). Podstawowym mankamentem takich badań jest fakt, że nie stanowią one podstawy oceny stanu liny na całej długości a przyczyną tego ograniczenia jest miejsce pobrania próby do badań - bezpośrednio znad zamocowania liny do naczynia wyciągowego. Mogą one stanowić jedynie podstawę do szacunkowej oceny zmian cech wytrzymałościowych liny.

W celu rozszerzenia wnioskowania na podstawie tych badań niezbędne byłoby znalezienie relacji między cechami uzyskanymi na badanym fragmencie liny a wynikami badań na całej długości liny, o ile taka zależność w ogóle istnieje. Na podstawie odpowiednio licznego zbioru wyników takich uzupełniających badań można byłoby opracować metodę pozwalającą określić prawdopodobieństwo zmiany (zmniejszenia się) w funkcji czasu pracy wartości cech wytrzymałościowych o określoną wartość.

W drugim przypadku badań wytrzymałościowych próbek pobranych z liny odłożonej uzyskuje się 
najwięcej informacji o niej, przy czym mogą one być wykorzystane jedynie jako wskazówki odnośnie użytkowania innych lin użytkowanych w podobnych systemach linowych.

\section{Wyniki badań i ich interpretacja}

Podstawowy cel niniejszej pracy został zdefiniowany już na wstępie niniejszego opracowania i jest nim stwierdzenie na ile rezultaty oceny stanu liny różnymi metodami są zbliżone. Analizę porównawczą zrealizowano przeprowadzając porównanie między stopniami osłabienia liny stwierdzonymi za pomocą badań magnetycznych i wytrzymałościowych.

Jako miarę osłabienia liny $w$ badaniach magnetycznych przyjęto zmianę (ubytek) przekroju liny F. W badaniach wytrzymałościowych tą miarą jest zmiana wartości siły rozciągającej $P$ jaką może lina przenieść. Obie miary są ściśle ze sobą związane gdyż łączy je ogólnie znana zależność $\sigma=P / F$. Przyjmując, że dopuszczalne naprężenia na rozciąganie dla danego materiału są w przybliżeniu stałe w czasie, analizowane wielkości są więc wprost proporcjonalne do siebie.

\section{Osłabienie liny określone}

na podstawie badań magnetycznych

Obliczeń ubytku przekroju dokonano na podstawie zapisu wewnętrznego czujnika pomiarowego - ścieżka III na rysunku 2 . Przedstawiony na tym rysunku fragment defektogramu dotyczy jednego z odcinków na jakie podzielono pobrany do badań fragment liny. Badania przeprowadzono przy następujących danych wejściowych:

- czułość badania: $10 \mathrm{mV} / \mathrm{mm}$

- odcinek sumowania: $40 \mathrm{~d}=1360 \mathrm{~mm}$ (dla liny $\mathrm{d}=34 \mathrm{~mm}$ ),

- przełożenie ruchu taśmy rejestratora: $20 \mathrm{~mm} / \mathrm{m}$,

- liczba impulsów na odcinku sumowania: 15.

Na podstawie zarejestrowanego przebiegu stwierdzono:

- średnia wysokość impulsu: 5,1 mm,

- odczytany z wykresu kalibracyjnego umowny ubytek przekroju dla średniego pojedynczego uszkodzenia: $\mathrm{U}_{\phi \mathrm{i}}=7,96 \mathrm{~mm}^{2}$.

Rzeczywisty ubytek przekroju liny Urzi dla pojedyncze- go impulsu (jego wartości średniej) oblicza się z zależności $[2,5]$ :

$$
U_{r z i}=\frac{U_{\phi i}}{k_{v} k_{s} k_{\rho} F_{n}} \cdot 100 \%
$$

w której k to współczynniki ujmujące zależność wskazań defektografu od:

$\mathrm{k}_{\mathrm{v}}$ - prędkości przesuwu liny,

$\mathrm{k}_{\mathrm{s}}$ - długości szczeliny spowodowanej pękniętym drutem, $\mathrm{k}_{\mathrm{p}}$ - odległości uszkodzenia od osi liny.

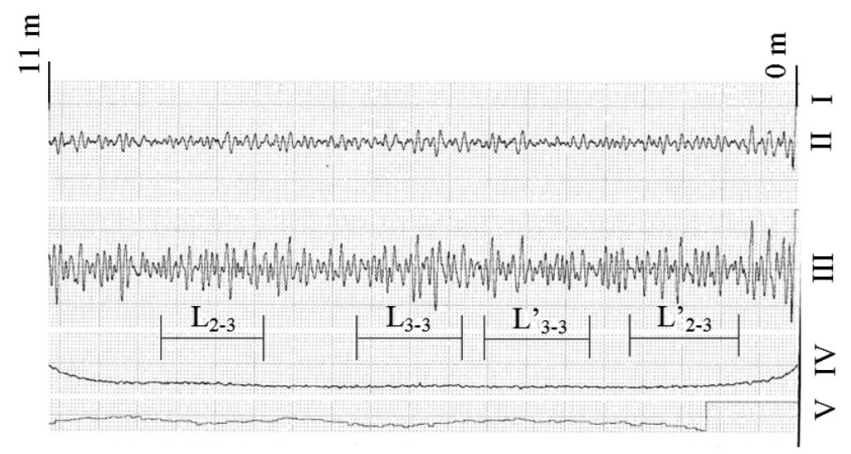

Rys. 2. Fragment defektogramu uzyskanego $w$ badaniach magnetycznych liny dla $p=20 \mathrm{~mm} / \mathrm{m}$, z wyróżnionymi ścieżkami zapisu: I - bieżąca długość liny, II - z zewnętrznego czujnika pomiarowego, III - z czujnika wewnętrznego, IV -z czujnika hallotronowego, $\mathrm{V}-\mathrm{z}$ integratora sumującego uszkodzenia na dł. $40 \mathrm{~d}$

Fig. 2. Defectogram fragment obtained in rope magnetic tests for $p=20 \mathrm{~mm} / \mathrm{m}$, with discriminated record paths: I - current rope length, II - from outer detecting element, III - from inner detecting element, IV - from Hall-effect element, V - from integrator summated failures on $40 \mathrm{~d}$ distance

Wartości współczynników k w powyższym wzorze, przyjmowane zgodnie $z$ normą [2] i wykresami kalibracyjnymi, wynoszą: $k_{v}=1, k_{s}=1, k_{\rho}=1,3$ dla $\rho=6 \mathrm{~mm}$, a sumaryczne nominalne pole przekroju drutów, $F_{n}=517,5 \mathrm{~mm}^{2}$. Przy tych danych wartość $U_{\text {rzi }}$ wynosi:

$$
U_{r z i}=\frac{7,96}{1 \cdot 1 \cdot 1,3 \cdot 517,5} \cdot 100 \%=1,18 \%
$$

Tablica I. Ubytek przekroju odcinka liny określony na podstawie badań magnetycznych przy różnych ich parametrach Table I. Decrement of rope segment intersection obtained on the ground of magnetic tests at different their parameters

\begin{tabular}{|c|c|c|c|c|c|c|}
\hline $\begin{array}{c}\text { Badana wielkość } \\
\text { Oznaczenie } \\
\text { odcinka }\end{array}$ & $\mathrm{L}_{2-1}$ & $\mathrm{~L}_{2-1}$ & $\mathrm{~L}_{2-2}$ & $\mathrm{~L}_{2-2}$ & $\mathrm{~L}_{2-3}$ & $\mathrm{~L}_{2-3}$ \\
\hline przekrój nominalny, $\mathrm{F}_{\mathrm{n}}\left[\mathrm{mm}^{2}\right]$ & \multicolumn{5}{|c|}{$\mathbf{5 1 7 , 5}$} \\
\hline
\end{tabular}

a) dla przełożenia ruchu taśmy rejestratora $p=10 \mathrm{~mm} / \mathrm{m}$

\begin{tabular}{|c|c|c|c|c|c|}
\hline sumaryczna zmiana przekroju [mm²] & 77,78 & 63,93 & 74,24 & 54,53 & 73,94 \\
\hline względna zmiana [\%] & 15,03 & 12,35 & 14,35 & 10,54 & 14,28 \\
\hline
\end{tabular}

b) dla przełożenia ruchu taśmy rejestratora $p=20 \mathrm{~mm} / \mathrm{m}$

\begin{tabular}{|c|c|c|c|c|c|}
\hline sumaryczna zmiana przekroju [mm²] & 91,64 & 81,70 & 88,17 & 62,07 & 89,09 \\
\hline względna zmiana [\%] & 17,71 & 15,78 & 17,04 & 11,99 & 17,21 \\
\hline
\end{tabular}


Ubytek przekroju całej liny $\bigcup_{\mathrm{rzc}}$ liczony na odcinku o długości $40 d$ wynosi [5]:

$$
U_{r z c}=\sum_{i=1}^{i=15} U_{r z i}=15 \cdot 1,18=17,71 \%
$$

Zestawienie określonych $\mathrm{w}$ badaniach magnetycznych zmian pola przekroju kilku odcinków lin zawarto w tablicy I.

Dla poszczególnych badanych odcinków zarejestrowano różnice przekraczające 5\%. Różnice takie stwierdzono porównując rezultaty badań tych samych odcinków lecz przy innych prędkościach przesuwu taśmy rejestratora. Różnice te nie przekraczały $3 \%$.

Dla porównania wyników, ubytek przekroju $\bigcup_{\text {Irz }}$ określono także na podstawie zapisu sygnału integrowanego - ścieżka $\vee$ na rysunku 2. Wyznaczono go przy danych:

- $U_{1}$ - wartość odczytana z wykresów kalibracyjnych dla maksymalnego wychylenia pisaka od położenia zerowego: $135 \mathrm{~mm}^{2}$,

$-\mathrm{k}_{\mathrm{v}}=1, \mathrm{k}_{\mathrm{s}}=1, \mathrm{k}_{\rho}=1,1$ dla $\rho=6 \mathrm{~mm}$.

$$
U_{I r z}=\frac{U_{I}}{k_{v} \cdot k_{s} \cdot k_{\mathrm{\rho}} \cdot F_{n}} \cdot 100 \%
$$

Przy powyższych danych ubytek przekroju liczony według (3) wynosi:

$$
U_{\text {Irz }}=\frac{135}{1 \cdot 1 \cdot 1,1 \cdot 517,5} \cdot 100 \%=23,72 \%
$$

Uzyskana wartość jest znacząco większa niż otrzymana w wyniku pomiarów innymi czujnikami. Z tego też powodu sygnałów z integratora nie wykorzystuje się do określenia stopnia osłabienia liny lecz jedynie do wskazania miejsca największego osłabienia przekroju.

\section{Osłabienie liny określone}

na podstawie badań wytrzymałościowych

W celu określenia osłabienia liny na podstawie badań wytrzymałościowych przyjęto następujące dane wejściowe i oznaczenia:

a) dla liny nowej (oznaczono indeksem $N$ ):

- siła zrywająca linę w całości, $P_{z(N)}=755800 \mathrm{~N}$,

- sumaryczna siła zrywająca wszystkie druty, $P_{\Sigma(N)}$ $=846020 \mathrm{~N}$;

b) dla liny używanej (z własnych badań wytrzymałościowych, oznaczone indeksem $U$ ):

- siła zrywająca linę w całości, $P_{z(U)}=750200 \mathrm{~N}$,

- sumarycznasiłazrywającawszystkiedruty, $P_{\Sigma(U)}=780820 \mathrm{~N}$. Wyniki badań wytrzymałościowych odcinków lin w całości zawarto w tablicy II. Stwierdzone duże zróżnicowanie zmian w poszczególnych odcinkach można tłumaczyć różnym stopniem zużycia liny - próbki do badań pobierane były z różnych miejsc.

Wpływ na rozrzut wyników mogły mieć również geometryczne cechy konstrukcyjne badanych odcinków, a także - w pewnym, lecz niewielkim zakresie - niejednakowe przygotowanie próbek do zrywania.

Wyniki uzyskane w badaniach wytrzymałościowych pojedynczych drutów zestawiono w tablicy III. Przy tym kryterium oceny stwierdzone osłabienie liny wynosi niecałe $10 \%$, jest więc mniejsze niż określone w badaniach magnetycznych dla całej liny, lecz znacznie większe niż zmniejszenie siły zrywającej linę w całości (badania wytrzymałościowe).

Porównując względne zmiany sumarycznej siły zrywającej, uzyskane dla poszczególnych odcinków liny, wyniki można uznać za prawidłowe. Występujące między odcinkami różnice nie przekraczają $2 \%$, można więc przyjąć je jako odchyłki statystyczne, wynikające przede wszystkim z niedokładności pomiarów, a także z losowości geometrycznych cech konstrukcyjnych.

Różnice w wynikach badań wytrzymałościowych lin w całości (tablica II) są trudne do zinterpretowania. W badaniach wytrzymałościowych stwierdzono, że w 6 badanych odcinkach siła zrywająca zmniejszyła się średnio $2,82 \%$ i tę wartość należy uznać za rzeczywiste osłabienie liny.

Wyznaczona na podstawie badań magnetycznych zmiana (ubytek) przekroju nośnego odpowiadających odcinków liny wynosi średnio $13,77 \%$ (dla $p=10)$ i jest to wynik najbardziej zbliżony do rezultatów badań wytrzymałościowych.

\begin{tabular}{|c|c|c|c|c|c|c|}
\hline $\begin{array}{l}\text { Badana wielkość } \\
\text { Oznaczenie } \\
\text { odcinka }\end{array}$ & $\mathrm{L}_{2-1}$ & $\mathrm{~L}_{2-1}^{\prime}$ & $\mathrm{L}_{2-2}$ & $\mathrm{~L}^{\prime 2-2}$ & $\mathrm{~L}_{2-3}$ & $\mathrm{~L}_{2-3}$ \\
\hline $\begin{array}{c}\text { nominalna siła zrywająca nową linę } \\
\qquad P_{z(N)} \\
{[N]}\end{array}$ & \multicolumn{6}{|c|}{755800} \\
\hline $\begin{array}{c}\text { siła zrywająca zużytą linę, } P_{z(N)} \\
{[N]}\end{array}$ & 739100 & 736000 & 727600 & 715400 & 750200 & 738700 \\
\hline $\begin{array}{l}\text { zmiana wartości siły zrywającej } \\
{[\mathrm{N}]}\end{array}$ & -16700 & -19800 & -28200 & -40400 & -5600 & -17100 \\
\hline $\begin{array}{c}\text { względna zmiana } \\
{[\%]}\end{array}$ & 2,21 & 2,62 & 3,73 & 5,35 & 0,74 & 2,26 \\
\hline
\end{tabular}

Tablica II. Zestawienie wyników badań odcinków liny zrywanych w całości Table II. Statement of research results of whole rope tensile test 
Tablica III. Sumaryczna siła zrywająca pojedyncze druty poszczególnych odcinków lin

Table III. Summary tensile force of individual rope segments each wires

\begin{tabular}{|c|c|c|c|c|c|c|}
\hline $\begin{array}{l}\text { Badana wielkość } \\
\text { Oznaczenie odcinka }\end{array}$ & $\mathrm{L}_{2-1}$ & $\mathrm{~L}_{2-1}$ & $\mathrm{~L}_{2-2}$ & $\mathrm{~L}_{2-2}$ & $\mathrm{~L}_{2-3}$ & $\mathrm{~L}_{2-3}$ \\
\hline $\begin{array}{c}\text { nominalna sumaryczna } \\
\text { siła zrywająca } \\
{[\mathrm{N}]}\end{array}$ & \multicolumn{6}{|c|}{846020} \\
\hline $\begin{array}{c}\text { określona sumaryczna } \\
\text { siła zrywająca } \\
{[\mathrm{N}]}\end{array}$ & 774520 & 777400 & 788860 & 791100 & 780820 & 786540 \\
\hline $\begin{array}{l}\text { zmiana wartości siły } \\
{[\mathrm{N}]}\end{array}$ & 71500 & 68620 & 57160 & 54920 & 65200 & 59480 \\
\hline $\begin{array}{c}\text { względna zmiana siły } \\
{[\%]}\end{array}$ & 8,45 & 8,11 & 6,76 & 6,49 & 7,71 & 7,03 \\
\hline
\end{tabular}

\section{Podsumowanie i wnioski}

Na podstawie przeprowadzonych badań i analiz można sformułować pewne spostrzeżenia i wnioski. Po to aby zaproponować wdrożenie ich do praktyki należy jeszcze zweryfikować je w dalszych badaniach eksperymentalnych lin stalowych. Do najistotniejszych rezultatów badań zaliczyć można poniższe:

- badania magnetyczne wykazują znacząco większe osłabienie liny niż stwierdzono to w badaniach wytrzymałościowych,

- parametry badań magnetycznych mają wpływ na uzyskane wyniki pomiarów.

Z przeprowadzonych badań wynika, że badania magnetyczne mają duży margines bezpieczeństwa i należy zastanowić się czy nie można tego marginesu zawęzić, np. poprzez wprowadzenie współczynnika korygującego do zależności, wg których liczy się osłabienie liny. Wprowadzenie kolejnego współczynnika do badań magnetycznych lin spowodowałoby zbliżenie oceny stanu liny do jej rzeczywistego stanu, co przyczyniłoby się do wydłużenia czasu jej użytkowania bez pogarszania bezpieczeństwa użytkowania obiektu. Po to, aby nie zmniejszyć bezpieczeństwa pracy urządzeń linowych wartość takiego współczynnika powinna być wyznaczona statystycznie na podstawie badań o dużej liczności próby.

\section{Literatura}

[1] Norma PN-66/G-46602: Liny kopalniane wyciągowe z drutów okrągłych. Liny nośne trójkątnosplotkowe.

[2] Norma PN-92/G-46603: Liny stalowe okrągłe. Oznaczenie stopnia zużycia metodą magnetyczną.

[3] Norma PN-EN 12385-2:2004. Liny stalowe. Bezpieczeństwo, część 2: Definicje, oznaczenia i klasyfikacja.

[4] Rozporządzenia Ministra Gospodarki z dnia 28.06.2002r. w sprawie bezpieczeństwa i higieny pracy, prowadzenia ruchu oraz specjalistycznego zabezpieczenia przeciwpożarowego w podziemnych zakładach górniczych. Dz. U. Nr 139, poz. 1169 z 2002r., Nr 124, poz. 863 z 2006r., Nr 126, poz. 855 z 2010r.

[5] Kwaśniewski J.: Badania magnetyczne lin stalowych. Wydawnictwa Akademii Górniczo-Hutniczej, Kraków 2010.

[6] Styp-Rekowski M., Mańka E.: Environmental Factors of Rope Hoisting Shaft Wear and Reliability. Proceedings of $X$ International Conference "Tribology and Reliability". Petersburg State Transport University Publishing, St. Petersburg (Russia) 2010, pp. 245-257.

[7] Tytko A.: Eksploatacja lin stalowych. Wydawnictwo Śląsk, Katowice 2003.

[8] Ładecki B.: Problemy związane z wykrywaniem pęknięć zmęczeniowych osi kolejowych, Przegląd Spawalnictwa, nr 11/2014, s. 28-34.

[9] Wojas G.: Badania nieniszczące w praktyce inspekcji dozorowej, Przegląd Spawalnictwa, nr 10/2014, s. 25-30.

[10] Wojas G.: Zagadnienia jakości badań nieniszczących. Wymagania ogólne w zakresie kompetencji laboratoriów badawczych, Przegląd Spawalnictwa, nr 12/2015, s. 62-67.

[11] Norma PN-68/M-80200: Liny stalowe. Podział i zasada budowy oznaczenia. 